\title{
Comparison of bulk-tank standard plate count and somatic cell count for Wisconsin dairy farms in three size categories
}

\author{
S. C. Ingham, ${ }^{* 1}$ Y. Hu, ${ }^{*}$ and C. Ané† \\ *University of Wisconsin-Madison, Department of Food Science, 1605 Linden Drive, Madison 53706 \\ †University of Wisconsin-Madison, Departments of Botany and Statistics, 1300 University Avenue, Madison 53706
}

\begin{abstract}
The objective of this study was to evaluate possible claims by advocates of small-scale dairy farming that milk from smaller Wisconsin farms is of higher quality than milk from larger Wisconsin farms. Reported bulk tank standard plate count (SPC) and somatic cell count (SCC) test results for Wisconsin dairy farms were obtained for February to December, 2008. Farms were sorted into 3 size categories using available sizetracking criteria: small ( $\leq 118$ cows; 12,866 farms), large (119-713 cattle; 1,565 farms), and confined animal feeding operations ( $\geq 714$ cattle; 160 farms). Group means were calculated (group $=$ farm size category) for the farms' minimum, median, mean, 90th percentile, and maximum SPC and SCC. Statistical analysis showed that group means for median, mean, 90th percentile, and maximum SPC and SCC were almost always significantly higher for the small farm category than for the large farm and confined animal feeding operations farm categories. With SPC and SCC as quality criteria and the 3 farm size categories of $\leq 118,119$ to 713 , and $\geq 714$ cattle, the claim of Wisconsin smaller farms producing higher quality milk than Wisconsin larger farms cannot be supported.
\end{abstract}

Key words: standard plate count, somatic cell count, farm size

\section{INTRODUCTION}

In Wisconsin, dairy processing plants must test bulk tank milk from each dairy producer supplying them, and report at least one SPC and one SCC result each month to the state regulatory authorities (Wisconsin Department of Agriculture, Trade and Consumer Protection, 2008). The bulk-tank SPC for grade A milk cannot exceed 100,000 cfu/mL. Wisconsin grade B milk cannot have bulk tank SPC greater than 300,000 cfu/ $\mathrm{mL}$ (Wisconsin Department of Agriculture, Trade and

Received February 25, 2011.

Accepted May 9, 2011.

${ }^{1}$ Corresponding author: ingham.steve@yahoo.com
Consumer Protection, 2008). Higher SPC values trigger a range of regulatory responses, including permit suspension, and are likely caused by lapses in sanitation or inadequate refrigeration. The maximum SCC level allowed for grade A or grade B bulk tank milk is 750,000 somatic cells/mL; SCC values above the maximum also lead to a variety of regulatory actions that may include permit suspension. The SCC of bulk tank milk is often used as a measure of mammary disease or mastitis in a dairy herd, and has been proposed for use in statistical process control as an indicator of ongoing herd health (Lukas, et al., 2005). A study of Wisconsin dairy herds enrolled in a milk quality improvement program found that bulk-tank SCC was positively associated with bulk tank SPC, estimated rate of clinical mastitis, prevalence of subclinical mastitis, number of cows culled for mastitis, and estimated financial losses attributable to mastitis (Rodrigues et al., 2005). Another study of Wisconsin herds found that the rate at which milk contained antibiotic residues increased as the SCC class (ranging from $\leq 250,000$ to $>700,000$ cells $/ \mathrm{mL}$ ) increased (Ruegg and Tabone, 2000). The SCC of a farm's bulk tank milk may also be related to overall farm hygiene and upkeep. A recent study of on-site dairy farm inspection and laboratory milk testing results in Wisconsin showed that the rate at which monthly bulk-tank milk samples failed to meet the grade A SCC limit was linked to an increased likelihood of failing an on-site dairy farm inspection (Ingham et al., 2010). On-site dairy farm inspections include evaluation of the cows, milk house, and barn for cleanliness, and observation of the condition and the sanitary upkeep of the milking equipment (Wisconsin Department of Agriculture, Trade and Consumer Protection, 2008). Collectively, the SPC and SCC for bulk tank milk are widely viewed as an indicator of dairy farm sanitation and animal-handling practices, and can be used by processors and consumers as indicators of milk quality.

Some consumers believe that small-scale dairy farms produce milk that is of higher quality than the milk produced by large-scale farms. Although the term quality is subjective and multi-faceted, bulk tank SPC and 
SCC can be used as 2 measures of quality. Advocates for small-scale dairy operators may believe that these farmers have a greater stake in successful farm operation than do operators of large-scale farms and will, thus, take greater care to hygienically collect milk and refrigerate it. Small-scale dairying supporters may also assert that dairy cows are less likely to be intensively milked on small-scale farms, will be less likely to contract mastitis, and thus, will produce milk with a lower SCC.

Opponents of these views may state that large-scale dairy operations are more likely to expend the resources necessary to purchase the most effective sanitation and refrigeration equipment, which, when used correctly, will lead to lower SPC. Opponents may also state that the negative consequences of mastitis in a large herd provide a financial incentive to rapidly remove infected cows from the herd and treat them before their milk is collected in the bulk tank. The possibility also exists that larger herd sizes allow the milk from a small proportion of mastitic cows to be diluted such that the bulk tank SCC remains low.

The present study was conducted to investigate existing SPC and SCC data and determine whether the average minimum, median, mean, 90th percentile and maximum levels of SPC and SCC differ between Wisconsin farm size categories.

\section{MATERIALS AND METHODS}

\section{Source of Data}

Wisconsin food safety regulatory authorities do not collect information on the milk output from each dairy producer. However, dairy farm inspectors do note on their reports when a producer's output is more than $2,944.5 \mathrm{~kg} / \mathrm{d}(6,500 \mathrm{lb} / \mathrm{d})$. The average daily milk production on Wisconsin dairy farms is $25.0 \mathrm{~kg}(55.2 \mathrm{lb}) /$ cow, so $2,944.5 \mathrm{~kg} / \mathrm{d}$ represents the output from about 118 average cows - somewhat higher than the most recently reported average dairy farm size in Wisconsin (95.5 cows; USDA, 2010). In the present study, farms with production below the $2,944.5 \mathrm{~kg} / \mathrm{d}$ level were categorized as small. A database of all dairy producer license numbers, along with monthly SPC and SCC results for each license-holder during February to December, 2008, was obtained from the Wisconsin Department of Agriculture, Trade and Consumer Protection (Madison). Wisconsin dairy farms with at least 714 cows must be issued a Confined Animal Feeding Operation (CAFO) permit by the state natural resources regulatory agency. In this study, dairy producers with $\geq 714$ cattle were placed in the CAFO category. A list of CAFO dairy op- erations was obtained from a Wisconsin Department of Natural Resources Web site (http://dnr.wi.gov/runoff/ agriculture/cafo/permits/cafo-all.asp). Dairy producers with an output of more than $2,944.5 \mathrm{~kg} / \mathrm{d}$, but who did not hold a CAFO permit were categorized as large. Monthly SPC and SCC results for each farm in the small, large, or CAFO size categories were extracted from the all-farms database described earlier. In total, 12,866 small farms, 1,565 large farms, and $160 \mathrm{CAFO}$ farms were evaluated. The SPC and SCC results were obtained from analyses done in licensed laboratories using methods approved by the US Food and Drug Administration (US FDA, 2011).

\section{Statistical Evaluation of Data}

The minimum, median, mean, 90th percentile, and maximum values were calculated for the $\leq 11 \mathrm{SPC}$ and for the $\leq 11$ SCC results obtained for each farm. Group means were calculated, with group mean defined as the average minimum, median, mean, 90th percentile, or maximum for SPC or SCC for a given farm size category.

To detect statistically significant differences between farm size categories, the SPC and SCC values were $\log$ transformed, because the original data value distributions were strongly skewed with unequal variances across groups. Even after log transformation, the SPC and SCC values were still quite non-normally distributed and had unequal variances across groups. Therefore, each variable listed in Table 1 was analyzed using the nonparametric Kruskal-Wallis rank sum test, to detect overall differences among groups. Pairwise comparisons between groups were then conducted by using the Wilcoxon rank sum test with a Bonferroni correction, which consisted of comparing $P$-values to the corrected standard of $0.05 / 3$ or 0.017 . Results obtained using one-way ANOVA and Tukey pairwise comparisons on the log-transformed values were qualitatively similar to those obtained using the Kruskal-Wallis rank sum test and Wilcoxon and Bonferroni analyses.

\section{RESULTS AND DISCUSSION}

\section{SPC Group Means}

The group means for mean and median SPC, as well as for mean and median SCC, were well below the grade A maximum values (Table 1). The group means for mean SPC were about 58,700, 36,300, and 35,000 cfu/ $\mathrm{mL}$, respectively, for the small, large, and CAFO farm size categories. The group means for median SPC were $31,300,26,000$ and $25,400 \mathrm{cfu} / \mathrm{mL}$, respectively, for the 
Table 1. Group mean values for minimum, median, mean 90th percentile, and SPC and SCC for small $(\leq 118$ cows), large (119-713 cattle), and confined animal feeding operations (CAFO; $\geq 714$ cattle) farm size categories

\begin{tabular}{|c|c|c|c|}
\hline Item & $\begin{array}{l}\text { Small farms } \\
(\mathrm{n}=12,866)\end{array}$ & $\begin{array}{c}\text { Large farms } \\
(\mathrm{n}=1,565)\end{array}$ & $\begin{array}{c}\text { CAFO farms } \\
(\mathrm{n}=160)\end{array}$ \\
\hline \multicolumn{4}{|c|}{$\mathrm{SPC}\left(\times 10^{4} \mathrm{cfu} / \mathrm{mL}\right)$} \\
\hline Minimum & $25,700^{\mathrm{a}}$ & $25,100^{\mathrm{b}}$ & $25,000^{\mathrm{ab}}$ \\
\hline Median & $31,300^{\mathrm{a}}$ & $26,000^{\mathrm{b}}$ & $25,400^{\mathrm{b}}$ \\
\hline Mean & $58,700^{\mathrm{a}}$ & $36,300^{\mathrm{b}}$ & $35,000^{\mathrm{ab}}$ \\
\hline 90th percentile & $100,100^{\mathrm{a}}$ & $46,800^{\mathrm{b}}$ & $40,500^{\mathrm{b}}$ \\
\hline Maximum & $250,200^{\mathrm{a}}$ & $110,500^{\mathrm{b}}$ & $113,600^{\mathrm{ab}}$ \\
\hline \multicolumn{4}{|c|}{$\mathrm{SCC}\left(\times 10^{5}\right.$ cells $\left./ \mathrm{mL}\right)$} \\
\hline Minimum & $209,000^{\mathrm{a}}$ & $183,000^{\mathrm{b}}$ & $179,000^{\mathrm{ab}}$ \\
\hline Median & $348,000^{\mathrm{a}}$ & $266,000^{\mathrm{b}}$ & $239,000^{\mathrm{c}}$ \\
\hline Mean & $369,000^{\mathrm{a}}$ & $273,000^{\mathrm{b}}$ & $240,000^{\mathrm{c}}$ \\
\hline 90th percentile & $511,000^{\mathrm{a}}$ & $344,000^{\mathrm{b}}$ & $288,000^{\mathrm{c}}$ \\
\hline Maximum & $625,000^{\mathrm{a}}$ & $394,000^{\mathrm{b}}$ & $313,000^{\mathrm{c}}$ \\
\hline
\end{tabular}

${ }^{a-c}$ Different superscript letters within a row indicate that $P<0.017$ for pairwise comparison of group means using the Wilcoxon rank sum test.

3 categories. Each of these group means was considerably less than the $100,000 \mathrm{cfu} / \mathrm{mL}$ grade A maximum. However, a 1993 to 1996 study of bulk tank SPC from 855 randomly selected New York farms (about 10\% of the state's farms) found mean and median SPC values of 11,400 and 10,000 cfu/mL, respectively (Boor et al., 1998). In all 3 farm-size categories in the present study, the group means for minimum SPC were at or only slightly above the analytical detection limit of 25,000 $\mathrm{cfu} / \mathrm{mL}$. The group mean 90 th percentile SPC for the small farm size category, $101,000 \mathrm{cfu} / \mathrm{mL}$, was above the grade A maximum, but the group mean 90th percentile SPC values for the large and CAFO farm size categories $(46,800$ and $40,500 \mathrm{cfu} / \mathrm{mL}$, respectively) were less than half of the grade A maximum. By comparison, the 90th percentile SPC in the 1993 to 1996 New York survey was $60,000 \mathrm{cfu} / \mathrm{mL}$ (Boor et al., 1998). The $90 \mathrm{th}$ percentile value for a 2002 national bulk tank milk survey was approximately 100,000 cfu/mL (Van Kessel et al., 2004). In the present study, the group mean for maximum SPC was above the grade A maximum in each of the 3 farm size categories.

\section{SCC Group Means}

The group means in the present study for mean SCC were 369,000 cells/mL for small farms, 273,000 cells/ $\mathrm{mL}$ for large farms, and 240,000 cells/mL for CAFO farms, all well below the 750,000 cells $/ \mathrm{mL}$ grade A maximum. These group means are comparable to the mean of 295,000 cells/mL found in a national bulk-tank milk survey done in 2002 (Van Kessel et al., 2004). They are also comparable to results from a 1995 to 1998 study of Wisconsin grade A dairy farms: a mean SCC of 335,000 cells/mL and a median SCC of 290,000 cells/mL (Ruegg and Tabone, 2000). Interestingly, the group means for 90th percentile SCC and maximum SCC for all 3 farm size categories were below the grade A maximum level. This result is consistent with the results of the 2002 national survey (Van Kessel et al., 2004). Consideration of the relatively low group means for 90th percentile SCC, along with the relatively high group means for 90th percentile SPC, suggests that (1) Wisconsin farmers are generally doing a better job of maintaining herd health than maintaining sanitation and refrigeration, (2) most Wisconsin dairy farms are large enough that high-SCC milk from a few cows can effectively be diluted by low-SCC milk from healthy cows, or (3) the SPC grade A maximum level is comparatively more stringent than the $\mathrm{SCC}$ grade A maximum level.

\section{Comparison of Farm Size Categories}

The small farm size category in our study had the highest group means for median, mean, 90th percentile, and maximum SPC and SCC. Results of the KruskalWallis analysis are shown in Table 2. A highly significant difference always existed among all farm size categories in the various group means $(P \leq 0.002$; Table 2 , first column). Pairwise comparisons showed that the group means for the small farm size category always significantly differed from group means for the large farm size category $(P \leq 0.001$; Table 2 , second column). Group means for farms in the small and CAFO farm size categories differed significantly except for minimum SPC, mean SPC, maximum SPC, and minimum SCC (Table 2 , third column; $P$-values of $0.176,0.034,0.089$, and 0.057 , respectively). Pairwise comparisons showed that SPC group means for farms in the large and CAFO farm size categories were never significantly different. The SCC group means, other than for minimum SCC 
Table 2. $P$-values obtained when comparing group means for minimum, median, mean, 90th percentile, and maximum SPC and SCC for small ( $\leq 110$ cows), large (111-713 cattle), and confined animal feeding operations $\left(\mathrm{CAFO} ; \geq 714\right.$ cattle) farm size categories ${ }^{1}$

\begin{tabular}{|c|c|c|c|c|}
\hline \multirow[b]{2}{*}{ Item } & \multirow{2}{*}{$\begin{array}{c}\text { Kruskal-Wallis test } \\
\begin{array}{c}\text { All farm size } \\
\text { categories }\end{array}\end{array}$} & \multicolumn{3}{|c|}{ Pairwise comparison } \\
\hline & & $\begin{array}{l}\text { Small vs. } \\
\text { large }\end{array}$ & $\begin{array}{c}\text { Small vs. } \\
\text { CAFO }\end{array}$ & $\begin{array}{c}\text { Large vs. } \\
\text { CAFO }\end{array}$ \\
\hline \multicolumn{5}{|l|}{$\overline{\mathrm{SPC}}$} \\
\hline Minimum & 0.002 & 0.001 & 0.176 & 0.52 \\
\hline Median & $4.0 \times 10^{-18}$ & $1.4 \times 10^{-17}$ & 0.005 & 0.99 \\
\hline Mean & $4.3 \times 10^{-5}$ & $5.8 \times 10^{-5}$ & 0.034 & 0.41 \\
\hline 90th percentile & $4.7 \times 10^{-9}$ & $7.0 \times 10^{-9}$ & 0.017 & 0.64 \\
\hline Maximum & $8.4 \times 10^{-4}$ & $6.3 \times 10^{-4}$ & 0.089 & 0.56 \\
\hline \multicolumn{5}{|l|}{ SCC } \\
\hline Minimum & $2.4 \times 10^{-9}$ & $1.3 \times 10^{-9}$ & 0.057 & 0.78 \\
\hline Median & $3.0 \times 10^{-88}$ & $8.9 \times 10^{-76}$ & $5.6 \times 10^{-18}$ & 0.008 \\
\hline Mean & $6.6 \times 10^{-121}$ & $3.3 \times 10^{-103}$ & $3.3 \times 10^{-24}$ & 0.001 \\
\hline 90th percentile & $7.6 \times 10^{-187}$ & $3.0 \times 10^{-158}$ & $5.4 \times 10^{-37}$ & $2.5 \times 10^{-6}$ \\
\hline Maximum & $1.4 \times 10^{-223}$ & $1.9 \times 10^{-187}$ & $1.5 \times 10^{-45}$ & $2.9 \times 10^{-9}$ \\
\hline
\end{tabular}

${ }^{1}$ The Kruskal-Wallis test was used to test for differences among the 3 farm size categories, and the Wilcoxon rank sum test was used to compare group means between each pair of farm size categories.

$(P=0.78)$, were significantly different between large and CAFO farm size categories $(P \leq 0.001$; Table 2 , fourth column).

\section{Discussion of Findings}

Collectively, the results of the present study suggest that sanitation or refrigeration lapses, or shortcomings in mastitis control, and consequent increases in SPC or SCC are most likely to occur on a farm in the small farm size category. An earlier study of Wisconsin farms enrolled in a milk quality improvement program (Rodrigues et al., 2005) found that, in comparison to smaller farms, large farms are more likely to have a freestall facility and are less likely to produce milk with SCC greater than 400,000 cells/mL. Mean SCC for bulk tank milk from freestall facilities was about 336,000 cells $/ \mathrm{mL}$, whereas the mean SCC for milk produced in stall barn facilities was significantly higher $(P=0.006)$ at about 430,000 cells/mL.

The advocacy of a particular scale of dairy farming may also coincide with advocacy for organic dairy farming practices. In Wisconsin, a survey on antimicrobial drug usage investigated organic and conventional farms that had a 6 -mo average SCC of $\geq 250,000$ cells $/ \mathrm{mL}$. The survey found that organic herds were generally smaller than conventional farms (72 vs. 197 lactating cows) and that no statistically significant association existed between the type of farming practiced and SCC or SPC (Pol and Ruegg, 2007). Half of the conventional farms had average SCC $\leq 299,000$ cells $/ \mathrm{mL}$ and $65 \%$ of the conventional farms had average SPC $<5,000 \mathrm{cfu} /$ $\mathrm{mL}$. Similarly, $60 \%$ of organic farms had average SCC $\leq 299,000$ cells $/ \mathrm{mL}$ and $50 \%$ of the organic farms had average $\mathrm{SPC}<5,000 \mathrm{cfu} / \mathrm{mL}$ (Pol and Ruegg, 2007). Differences between organic and conventional farms might be seen, however, in a survey done without the $\geq 250,000$ cells $/ \mathrm{mL}$ SCC criterion for inclusion.

Small-dairy advocates may claim that small-scale dairy farms produce higher-quality milk because they practice intensively managed rotational grazing. A study by Goldberg et al. (1992) found that milk from cattle fed using intensively managed rotational grazing practices had lower average SPC and similar average SCC compared with milk from cattle fed using traditional continuous grazing or in confinement housing. These results occurred regardless of whether the herd contained $<60$ or $\geq 60$ lactating cows. However, the size of this study was relatively small (60 farms), the standard deviations of mean SPC and SCC values were relatively high, and $P$-values used to establish statistical significance were higher than usual (0.10 and 0.15).

Advocates of small-scale dairy farming may also make claims about lower prevalence of pathogenic bacteria in bulk tank milk. The basis for this claim may be reportedly lower SPC values for milk from small-scale farms. Notwithstanding the fact that all but incidental onfarm sales of unpasteurized milk are illegal in Wisconsin (Wisconsin Department of Agriculture, Trade and Consumer Protection, 2008), little evidence is available to substantiate these claims. A national survey of 861 bulk tank milk samples done in 2002 found no statistically significant relationship between SPC or SCC and the presence of Salmonella (found in $2.6 \%$ of samples) or Listeria monocytogenes (found in $6.5 \%$ of samples) in bulk tank milk (Van Kessel et al., 2004). All farms enrolled in this study had at least 30 lactating cows at the time of the survey. Similar results were found 
by researchers at the University of Vermont when they analyzed the milk supply (cow, sheep, and goat) of 10 farmstead cheesemaking operations over a 13-wk period. No Salmonella spp. were isolated from any of the cow milk samples analyzed, but L. monocytogenes was found in 3 cow milk samples, 2 of which were from the same farm. Staphylococcus aureus was detected in $27.4 \%$ of cow milk samples, and Escherichia coli O157:H7 was detected in 1 goat milk sample but not in any cow milk sample. Of 123 milk samples tested for SPC, 96.8\% had SPC below $100,000 \mathrm{cfu} / \mathrm{mL}$, with mean and median values of 4,900 and $700 \mathrm{cfu} / \mathrm{mL}$, respectively (D'Amico et al., 2008). The authors concluded that the milk used at the cheesemaking plants was generally of good microbiological quality and that no link existed between $\mathrm{SPC}$ level and the presence of the food-borne pathogens studied.

In the present study, we investigated the possible claim that milk from small Wisconsin farms is generally of higher quality than milk from large Wisconsin farms. We conclude that such a claim is not scientifically supportable, at least when SPC and SCC are used as the quality indicators and the farm size categorizations are the ones used in the present study. Further research is necessary to investigate claims that milk from small farms is better than milk from large farms in terms of other objective or subjective quality parameters such as flavor and environmental impact.

\section{REFERENCES}

Boor, K. J., D. P. Brown, S. C. Murphy, S. M. Kozlowski, and D. K. Bandler. 1998. Microbiological and chemical quality of raw milk in New York State. J. Dairy Sci. 81:1743-1748.
D'Amico, D. J., E. Groves, and C. W. Donnelly. 2008. Low incidence of foodborne pathogens of concern in raw milk utilized for farmstead cheese production. J. Food Prot. 71:1580-1589.

Goldberg, J. J., E. E. Wildman, J. W. Pankey, J. R. Kunkel, D. B. Howard, and B. M. Murphy. 1992. The influence of intensively managed rotational grazing, traditional continuous grazing, and confinement housing on bulk tank milk quality and udder health. J. Dairy Sci. 75:96-104.

Ingham, S., W. VanHove, R. Jeutong, C. Adamson, R. Battaglia, and T. Leitzke. 2010. Short communication: Correlation of on-site inspection and laboratory milk test results for Wisconsin grade A dairy farms in 2007 and 2008. J. Dairy Sci. 93:3957-3960.

Lukas, J. M., D. M. Hawkins, M. L. Kinsel, and J. K. Reneau. 2005. Bulk tank somatic cell counts analyzed by statistical process control tools to identify and monitor subclinical mastitis incidence. J. Dairy Sci. 88:3944-3952.

Pol, M., and P. L. Ruegg. 2007. Treatment practices and quantification of antimicrobial drug usage in conventional and organic dairy farms in Wisconsin. J. Dairy Sci. 90:249-261.

Rodrigues, A. C. O., D. Z. Caraviello, and P. L. Ruegg. 2005. Management of Wisconsin dairy herds enrolled in milk quality teams. J. Dairy Sci. 88:2660-2671.

Ruegg, P. L., and T. J. Tabone. 2000. The relationship between antibiotic residue violations and somatic cell counts in Wisconsin dairy herds. J. Dairy Sci. 83:2805-2809.

USDA. 2010. 2010 Wisconsin Agricultural Statistics. National Agricultural Statistics Service. Wisconsin Department of Agriculture, Trade and Consumer Protection, Madison, WI.

US FDA. 2011. MI-05-3: Updated Official Laboratory Evaluation Forms (FDA - 2400 Series). US Food and Drug Administration. Accessed April 2, 2011. http://www.fda.gov/Food/FoodSafety/ Product-SpecificInformation/MilkSafety/CodedMemoranda/ MemorandaofInformation/ucm075155.htm.

Van Kessel, J. S., J. S. Karns, L. Gorski, B. J. McCluskey, and M. L. Perdue. 2004. Prevalence of salmonellae, Listeria monocytogenes, and fecal coliforms in bulk tank milk on US dairies. J. Dairy Sci. $87: 2822-2830$.

Wisconsin Department of Agriculture, Trade and Consumer Protection. 2008. Chapter ATCP60 Dairy Farms. Pages 411-430 in Wisconsin Register April 2008, No. 628. 